Adnan

p-ISSN 2621-3184 ; e-ISSN 2621-4032

doi: 10.36387/jifi.v4i1.694

\title{
EFEKTIVITAS CEFOTAXIME DAN CEFIXIME PADA DIARE AKUT KARENA INFEKSI DI BANGSAL ANAK RAWAT INAP DI SALAH SATU RUMAH SAKIT DI YOGAYAKARTA PERIODE JANUARI - DESEMBER 2018
}

\author{
Adnan*, Nurkhalisa Ekaputri \\ Fakultas Farmasi, Universitas Ahmad Dahlan \\ *:adnan@pharm.uad.ac.id
}

\begin{abstract}
ABSTRAK
Diare akut karena infeksi adalah buang air besar yang frekuensinya lebih sering dari bisanya (3 kali atau lebih per hari) dengan konsistensi tinja cair. Di Indonesia, angka kejadian diare akut masih tinggi setiap tahunnya dan masih menjadi permasalahan yang perlu diperhatikan secara serius. Cefotaxime dan cefixime adalah golongan antibiotika golongan sefalosporin yang bisa digunakan untuk kasus diare akut spesifik karena infeksi bakteri. Penelitian ini bertujuan untuk mengetahui perbandingan efektivitas penggunaan cefotaxime dibandingkan dengan cefixime di bangsal anak rawat inap di RSUD Panembahan Senopati Bantul periode januari-desember 2018. Jenis penelitian adalah observasional analitik dengan pengambilan data menggunakan metode retrospektif. Parameter efektifitas yang digunakan adalah lama waktu rawat inap. Hasil penelitian menunjukkan bahwa pasien diare akut karena infeksi anak paling banyak terjadi pada 57 pasien anak lakilaki $(65,5 \%)$ dan 30 pasien anak perempuan $(34,5 \%)$, dengan kelompok usia $<1$ tahun $(1,1 \%) ; 1-5$ tahun $(69,0 \%)$ dan 6-11 tahun $(29,9)$, pasien anak yang belum sekolah 66 anak $(75,9 \%)$ dan yang sedang menempuh SD 21 anak $(24,1 \%)$, dan penggunaan antibiotika yang paling banyak digunakan yaitu cefotaxime 59,8\%, cefixime yaitu 40,2\%. Perbandingan efektivitas cefotaxime dan cefixime dengan rata-rata lama rawat inap Cefixime (4,5hari) dan Cefotaxime (4,2hari). Kesimpulan dari penelitian ini tidak terdapat perbedaan bermakna pada lama rawat inap kedua antibiotik tersebut ( $p$ value $>0,05)$.
\end{abstract}

Kata kunci : Diare karena infeksi, cefotaxime, cefixime, lama rawat inap

\section{ABSTRACT}

Acute diarrhea due to infection is defecate more often than it can be (3 times or more per day) with the consistency of liquid stools. In Indonesia, the incidence of acute diarrhea is still high every year and is still a problem that needs serious attention. Cefotaxime and cefixime are cephalosporin antibiotics that can be used for specific cases of acute diarrhea because bacterial infection. This study aims to find out the comparison of the effectiveness of cefotaxime use compared to cefixime in inpatient children's wards at Panembahan Senopati Bantul Hospital from January to December 2018. This research is a type of analytical observational research with data retrieval using retrospective methods. The results showed that acute diarrhea 
Adnan

p-ISSN 2621-3184 ; e-ISSN 2621-4032

doi: 10.36387/jifi.v4i1.694

patients due to child infections occurred most in 57 male patients $(65.5 \%)$ and 30 female patients (34.5\%), with age groups <lyears (1.1\%); 1-5 years (69.0\%) and 6-11 year olds (29.9), unattended children 66 children (75.9\%) and those attending elementary school 21 children (24.1\%), and the most widely used use of antibiotics is cefotaxime 59.8\%, cefixime is $40.2 \%$. Comparison of the effectiveness of cefotaxime and cefixime with average the average length of hospitalization of Cefixime (4.5days) and Cefotaxime (4.2days). The conclusion of this study was no meaningful difference in the length of hospitalization of the two antibiotics ( $p$ value >0.05).

Keywords: Diarrhea due to infection, cefotaxime, cefixime, length of stay

\section{PENDAHULUAN}

Penyakit diare masih menjadi salah satu masalah kesehatan masyarakat yang penting karena merupakan penyumbang utama ketiga angka kesakitan dan kematian anak di berbagai negara belahan dunia termasuk Indonesia, sehingga dunia melalui WHO (World Health Organitaition) pada tahun 1984 menetapkan diare sebagai kedaruratan global. Di negara miskin dan negara berkembang, diare akut masih merupakan penyebab utama morbiditas dan mortalitas pada anak $^{1}$.

Di Indonesia angka kejadian diare akut diperkirakan masih sekitar 60 juta kejadian diare tiap tahunnya dan angka kesakitan pada kelompok balita sekitar 200-400 kejadian diare di antara 1000 penduduk setiap tahunnya dan $1-5 \%$ diantaranya berkembang menjadi diare kronik. Angka kesakitan diare di Kabupaten Bantul pada tahun 2017 sebesar 5,91 per 1000 penduduk meningkat bila dibandingkan dengan tahun 2016 sebesar 5,19 per 1000 penduduk dan dilaporkan bahwa $100 \%$ balita yang menderita diare sudah ditangani ${ }^{2}$.

Penelitian terkait penggunaan antibiotik cefixime dan cefotaxime sudah pernah dilakukakn oleh beberapa peneliti yaitu "Evaluasi Penggunaan Obat pada Pasien balita terkena Diare Pada Pasien Rawat Inap Di Rumah Sakit X Tahun 2014" oleh Septiani (2014), dengan hasil $87,5 \%$ menunjukkan bahwa antibiotik yang paling banyak digunakan adalah cefotaxime ${ }^{3}$. Serta penelitian berjudul "Kajian Penggunaan Antibiotik Pada Pasien Diare Akut Di Bangsal Rawat Inap Anak" oleh Trisnowati, dkk (2017), 
yang menunjukkan bahwa golongan antibiotik yang sering digunakan adalah golongan sefalosporin ${ }^{4}$.

Penyakit diare merupakan jenis yang masuk dalam 10 besar penyakit di RSUD Panembahan Senopati Bantul. Survei yang telah dilakukan pada Rumah Sakit ini, terapi antibiotik yang digunakan untuk pengobatan diare pada anak yaitu antibiotik golongan sefalosporin generasi ke-III (cefotaxime dan cefixime). Penggunaan antibiotik yang relatif tinggi belum tentu bisa menjamin efektivitas perawatan pasien, sehingga dilakukan penelitian untuk mengetahui efektivitas dari kedua antibiotik tersebut. Penelitian yang membuktikan efektivitas cefotaxime dibandingkan dengan cefixime pada diare karena infeksi masih sangat kurang dilakukan.

\section{METODE PENELITIAN}

\section{Jenis Peneltian}

Jenis penelitian ini adalah observasional analitik dengan pendekatan secara cross sectional secara retrospektif. Pengambilan data dilakukan pada bulan SeptemberDesember 2019.

\section{Subjek penelitian}

Populasi terjangkau dalam penelitian ini adalah pasien anak dengan diagnosis diare akut karena infeksi di RSUD Panembahan Senopati Bantul periode tahun 2018. Sampel penelitian yang digunakan dalam penelitian ini adalah pasien anak dengan diagnosis diare akut karena infeksi di RSUD Panembahan Senopati Bantul periode tahun 2018 yang memenuhi kriteria inklusi dan eksklusi. Kriteria inklusi meliputi: pasien anak usia 0 - 11 tahun yang didiagnosis diare karena infeksi dan pasien anak yang mendapatkan antibiotik cefotaxime dan cefixime. Kriteria eksklusi meliputi: pasien dengan data rekam medis yang tidak lengkap dan pasien yang meninggal selama periode tahun 2018. Pengambilan sampel penelitian dilakukan dengan teknik total sampling, yakni semua sampel yang memenuhi kriteria inklusi dijadikan sebagai sumber data. Dari 160 populasi didapatkan 87 pasien yang memenuhi kriteria inklusi.

\section{Variable penelitian}




\begin{abstract}
Variable bebas adalah pengunaan terapi antibiotik cefotaxime dan cefixime, sedangakan variable terikat dalam penelitian ini adalah lama rawat inap dari pasien.
\end{abstract}

Lama rawat inap adalah waktu yang dihitung sejak pasien masuk rumah sakit sampai pasien dinyatakan sembuh dan pulang dari rumah sakit. Kriteria lama rawat inap dibagi menjadi dua yaitu cepat dan lama, cepat jika waktu lama rawat inap kurang dari rata-rata waktu lama rawat inap secara keseluruhan dan kategori lama jika lama rawat inap lebih dari nilai rata-rata.

\section{Alat dan Bahan}

Alat yang digunakan berupa Lembar Pengumpulan Data (LPD) yang berisi kolom nomor rekam medis, umur, jenis kelamin, pendidikan, lama rawat inap, antibiotik yang diberikan, data subjektif, data objektif, obat lain yang diberikan, dan data laboratorium yang diisi berdasarkan catatan rekam medis pasien yang memenuhi kriteria inklusi. Bahan yang digunakan dalam penelitian ini berupa data rekam medis pasien diare karena infeksi yang menjalani perawatan di Instalasi Rawat Inap RSUD Panembahan Senopati Bantul periode januari-desember tahun 2018

\section{Jalannya Penelitian}

Rumah Sakit yang digunakan sebagai tempat pengambilan data dalam penelitian ini adalah RSUD Panembahan Senopati Bantul. Penelitian ini sudah mendapatkan persetujuan etik / Ethical Approval dari Komite Etik Penelitian RSUD Panembahan Senopati Bantul dengan nomor 070/5579, serta sudah mendapatkan ijin dari BAPPEDA Kab. Bantul, dan juga dari RSUD Panembahan Senopati Bantul. Pengambilan data penelitian bersumber dari data rekam medis pasien yang memenuhi kriteria inklusi dan eksklusi. Data yang diambil adalah usia, jenis kelamin, Pendidikan, lama rawat inap, antibiotik yang digunakan, data subjektif dan objektif serta pengobatan lain yang diterima pasien.

Analisis Data 
Untuk mengetahui adanya perbedaan efektifitas dianatara kedua antibiotik, digunakan uji Independent t test.

\section{HASIL DAN PEMBAHASAN}

Penelitian ini melibatkan 87 rekam medis pasien sebagai subjek penelitian yang sesuai dengan kriteria inklusi dan eksklusi dari populasi terjangkau sebesar 160 rekam medis yang ada.

A. Karakteristik Demografi Pasien

1. Usia

\begin{tabular}{ccc}
$\begin{array}{c}\text { Tabel 1. Karakteristik Pasien } \\
\text { Diare Akut Berdasarkan } \\
\text { Kelompok Usia }\end{array}$ \\
\hline $\begin{array}{c}\text { Kelompok } \\
\text { Usia } \\
\text { (tahun) }\end{array}$ & $\begin{array}{c}\text { Frekuensi } \\
\mathbf{n = 8 7}\end{array}$ & $\begin{array}{c}\text { Persentase } \\
(\%)\end{array}$ \\
\hline$<1$ & 1 & 1,1 \\
$1-5$ & 60 & 69,0 \\
$6-11$ & 26 & 29,9 \\
\hline Total & 87 & 100 \\
\hline
\end{tabular}

Dari tabel I mempelihatkan bahwa diare terjadi paling banyak pada kelompok usia 1-5 tahun yaitu 60 pasien $(69,0 \%)$. Hasil ini relevan dengan hasil penelitian Nabilah (2015) dimana kelompok usia yang paling banyak menderita diare akut anak adalah kelompok usia 1-5 tahun yaitu sebanyak 36 pasien $(90 \%)^{15}$. Hal ini menunjukkan bahwa anak di bawah 6 tahun lebih beresiko mengalami diare dibandingkan anak diatas 6 tahun. Berdasar riset oleh Kementrian Kesehatan menyampaikan bahwa proporsi terbesar penderita diare pada anak adalah pada kelompok usia 1-5 tahun. Berdasarkan data dari Riskesdas (2018) yang menunjukkan prevalensi diare pada anak balita di DIY (Daerah Istimewa Yogyakarta) mencapai $9 \% 5$. Tingginya angka kejadian diare pada anak berkaitan dengan daya tahan tubuh anak dimana anak usia kurang dari 5 tahun masih memiliki daya tahan tubuh yang rendah. Selain itu anak yang sudah memasuki umur 7 bulan ke atas sudah mulai mendapatkan makanan pendamping ASI sebagai asupan nutrisi. Di samping itu, makanan pendamping ASI yang didapatkan anak memiliki peluang lebih besar terkontaminasi dengan mikroba yang bisa menyebabkan infeksi dan anak yang sudah memulai mendapatkan makanan pendamping ASI juga mulai aktif bermain misalnya merangkak dan memainkan benda-benda di sekitarnya sehingga resiko terkena infeksi lebih besar dibanding anak 
yang belum aktif bermain dan beraktivitas

2. Jenis Kelamin

Tabel 2. Karakteristik Demografi Berdasarkan Jenis Kelamin

\begin{tabular}{ccc}
\hline $\begin{array}{c}\text { Jenis } \\
\text { Kelamin }\end{array}$ & $\begin{array}{c}\text { Frekuensi } \\
\mathbf{n = 8 7}\end{array}$ & Persentase(\%) \\
\hline Laki-laki & 57 & 65,5 \\
Perempuan & 30 & 34,5 \\
\hline Total & 87 & 100 \\
\hline & Jenis & kelamin laki-
\end{tabular}

laki menjadi merupakah jumlah terbanyak yang mengalami diare dalam penelitian ini yaitu 57 pasien $(65,5 \%)$. Hal ini relevan dengan penelitian yang dilakukan oleh Nabilah (2015) yang dilakukan di RS "X" di Kota Tangerang Selatan bahwa anak yang menderita diare akut karena infeksi yang paling banyak adalah pasien anak dengan jenis kelamin laki-laki yaitu sebanyak 24 pasien $(60 \%)^{11}$. La Ode (2014) dalam penelitiannya melaprkan bahwa penedrita diare terbanyak adalah laki-laki sebesar $(65,8)^{6}$. Penelitian serupa dilakukan oleh Iswari Yeni (2011) dengan besar sampel sebanyak 108 responden, sebagian besar anak yang menderita diare akut karena infeksi berjenis kelamin laki-laki dengan 72 pasie $(66,7 \%)^{7}$. Sukawaty (2017) dalam penelitiannya menyampaikan bahwa secara khusus belum ada penelitian atau teori yang menunjukkan adanya hubungan jenis kelamin dengan penyakit diare, baik anak laki-laki ataupun perempuan mempunyai peluang yang sama besar untuk menderita penyakit diare, selama penyebab timbulnya diare tetap merata di semua wilayah $^{8}$. Berdasarkan data Riskesdas (2018) prevalensi diare menurut kelompok jenis kelamin antara laki-laki dan prempuan hampir sama, yaitu $8,9 \%$ pada laki-laki dan $9,1 \%$ pada perempuan $^{5}$.

3. Tingkat Pendidikan

Tabel 3. Karakteristik Pasien Diare Akut Berdasarkan Tingkat

\begin{tabular}{ccc}
\multicolumn{3}{c}{ Pendidikan } \\
\hline $\begin{array}{c}\text { Pendidika } \\
\mathbf{n}\end{array}$ & $\begin{array}{c}\text { Frekuens } \\
\mathbf{i} \\
\mathbf{n}=\mathbf{8 7}\end{array}$ & $\begin{array}{c}\text { Persentase } \% \\
\text { ) }\end{array}$ \\
\hline Belum & 66 & 75,9 \\
$\begin{array}{c}\text { Sekolah } \\
\text { SD }\end{array}$ & 21 & 24,1 \\
\hline Total & 87 & 100 \\
\hline
\end{tabular}

Berdasar tingkat pendidikan, dalam penelitian ini diare paling banyak terjadi pada kelompok anak yang belum sekolah usia 0-5 tahun yaitu sebanyak 66 pasie $(75,9 \%)$. Almanfaluthi (2017) dalam penelitiannya juga melaporkan 
bahwa diare paling banyak terjadi pada kelompok belum sekolah yaitu terdapat 85 siswa $(85,5 \%)^{9}$. Pendidikan memegang peranan yang cukup penting dalam kesehatan. Dari data penelitian ini didapatkan bahwa kejadian diare terjadi pada kelompok pra sekolah atau belum sekolah. Dampak diare yang terlalu sering pada anak dapat menyebabkan gangguan saluran cerna, diantaranya adalah malabsorbsi (gangguan penyerapan) atau gangguan enzim pencernaan yang dapat menyebabkan masukan gizi yang tidak adekuat. Pada usia anak tersebut seharusnya anak memiliki gizi yang cukup untuk pertumbuhannya akan tetapi jika sering mengalami diare maka penyerapan gizi mereka akan terganggu. Dampak lainnya adalah jika anak sering sakit maka akan sering tidak masuk sekolah dan akan ketinggalan pelajaran ${ }^{10}$.

\section{B. Efektivitas}

Penggunaan Antibiotika

1. Terapi Antibiotika

Tabel 4. Jumlah Pasien Berdasarkan Antibiotika

\begin{tabular}{ccc}
\hline Antibiotika & Jumlah & Persentase \\
& Pasien & $(\%)$ \\
\hline
\end{tabular}

\begin{tabular}{clc}
\hline Cefotaxime & 52 & \multicolumn{2}{c}{59,8} \\
Cefixime & 35 & \multicolumn{2}{c}{40,2} \\
\hline Total & 87 & \multicolumn{2}{c}{100} \\
\hline Dari & tabel & di atas
\end{tabular}

menunjukkan bahwa antibiotik yang paling banyak digunakan adalah cefotaxime. Pada penelitian yang dilakukan oleh Nabilah (2015) di RS "X" di Kota Tangerang Selatan menunjukkan antibiotika yang paling banyak digunakan yaitu cefotaxime dibandingan dengan cefixime ${ }^{11}$. Cefotaxime adalah antibiotik golongan sefalosporin seperti sefepim, seftasidim, seftizoksim dan seftriakson. Cefotaxime merupakan sefalosporin amonitiazol parentral ${ }^{12}$.

2. Lama Rawat Inap

Tabel 5. Frekuensi Lama Rawat Inap

\begin{tabular}{ccccccccc} 
& \multicolumn{3}{c}{ Lama Rawat Inap } \\
& \multicolumn{9}{c}{$\begin{array}{c}\text { (hari) } \\
\end{array}$} & $\mathbf{2}$ & $\mathbf{3}$ & $\mathbf{4}$ & $\mathbf{5}$ & $\mathbf{6}$ & $\mathbf{7}$ & $\mathbf{8}$ \\
\hline $\begin{array}{c}\text { Jumlah Pasien } \\
\text { Menggunakan } \\
\text { Cefixime }\end{array}$ & 2 & 8 & 11 & 7 & 1 & 2 & 4 \\
$\begin{array}{c}\text { Jumlah Pasien } \\
\text { Menggunakan } \\
\text { Cefotaxime }\end{array}$ & 1 & 15 & 21 & 7 & 3 & 4 & 1 \\
\hline
\end{tabular}

Tabel V menunjukkan bahwa lama waktu rawat inap paling rendah adalah 2 hari dan yang paling lama adalah 8 hari untuk antibiotic cefixime dan cefotaxime. Dari tabel di atas diketahui rata-rata masingmasing antibiotika pasien diare akut 
karena infeksi. Parameter Rata-rata ini dijadikan acuan untuk pengukuran efektivitas dari lama perhitungan rata-rata lama rawat inap rawat inap adalah kurang dari sama masing-masing antibiotika dengan empat hari. Antibiotika dapat dikatakan efektif jika lama rawat inap pasien kurang dari empat hari.

3. Perbandingan

Penggunaan Antibiotika

Tabel 6. Group Statistics

\begin{tabular}{ccccccc}
\hline & Antibiotik & $\mathrm{N}$ & Mean & $\mathrm{T}$ & Sig & Ket \\
\hline \multirow{3}{*}{ Lama Rawat Inap } & Cefixime & \multirow{2}{*}{35} & 4,54 & & & \\
\cline { 2 - 4 } & & & & & & \\
& Cefotaxime & 52 & 4,26 & & 0,111 & Tidak berbeda bermakna \\
\hline
\end{tabular}

assumed diperoleh nilai $\mathrm{t}$ sebesar

Jika dilihat pada tabel Group Statistics diperoleh nilai mean pada cefotaxime sebesar 4,26 dan cefixime sebesar 4,54. Nilai tersebut menunjukkan rata-rata lama rawat inap pasien cefixime lebih tinggi dibandingkan dengan cefotaxime. Hal ini sesuai dengan penelitian Newman (2014) ${ }^{13}$ dan Mohan $(2014)^{14}$ bahwa durasi lama rawat inap hanya 3 hari atau dengan rentang 3-4 hari pada pemilihan terapi golongan sefalosporin. Dan juga diperoleh nilai $t$ sebesar 0,844 dan taraf signifikansi $p=0,401$. Hasil tersebut menunjukkan bahwa $p$ $>0,05$ yang berarti tidak terdapat perbedaan bermakna rata-rata lama rawat inap dari kedua antibiotik tersebut. pada equal variance 0,844 dan taraf signifikansi $\mathrm{p}=$ 0,401 . Hasil tersebut menunjukkan bahwa $p>0,05$ yang berarti tidak terdapat perbedaan bermakna ratarata lama rawat inap dari kedua antibiotik tersebut. Lama rawat inap dipengaruhi oleh beberapa faktor diantaranya umur pasien yang berbeda, dosis obat yang diberikan bervariasi, berat badan pasien yang berbeda, tingkat keparahan penyakit dan status imun pasien juga berbeda tiap individunya sehingga mempengaruhi hasil outcome klinis yang muncul setelah pemberian terapi ${ }^{15}$. Outcome klinis diukur dari waktu bebas demam dan lama rawat di rumah sakit, saat demam reda (time offever defervesence) merupakan parameter keberhasilan 
pengobatan dan saat tersebut menentukan efektivitas antibiotik ${ }^{16}$. Umur dan berat badan pasien berhubungan dengan dosis yang akan diberikan kepada pasien. Berat dan ringannya suatu penyakit (tingkat keparahan penyakit) juga mempengaruhi lamanya perawatan. Pada penelitian sebelumnya menunjukkan bahwa lama rawat inap pada pasien yang masuk dengan diagnosis lebih berat menunjukkan hari rawat inap yang lebih panjang dibandingkan pasien yang mulai rawat inap dengan diagnosis yang lebih ringan ${ }^{17}$.

\section{KESIMPULAN Berdasarkan hasil dari penelitian yang telah}

\section{DAFTAR PUSTAKA}

1. Kementerian kesehatan RI. (2011). Situasi DIARE di Indonesia. Buletin Jendela Data dan Informasi Kesehatan. 2(2): 1-6.

2. Dinkes (2018). Profil Kesehatan Kabupaten Bantul 2018. Dinas Kesehatan Pemerintah Kabupaten Bantul

3. Septiani, S., Cholisoh, Z., \& Pharm, M. C. (2016). Evaluasi Penggunaan Obat pada Pasien Balita Terkena Diare pada Pasien Rawat Inap RSUD Kota Surakarta berpengaruh terhadap lama rawat inap karena dilakukan pada pasien diare karena infeksi terhadap 87 pasien anak di Rumah Sakit Panembahan Senopati Bantul Periode januari-desember 2018 terhadap efektivitas penggunaan antibiotik cefotaxime dan cefixime dapat disimpulkan Rata-rata lama rawat inap pasien yang mendapatkan antibiotika Cefotaxime adalah (4,2 hari) dan Cefixime adalah (4,5 hari) dan tidak ada perbedaan yang signifikan mengenai efektivitas antara pemberian antibiotik cefotaxime dan cefixime berdasarkan lama rawat inap pada pasien anak diare karena infeksi.

Tahun 2014 (Doctoral dissertation, Universitas Muhammadiyah Surakarta).

4. Trisnowati, K. E., Irawati, S., \& Setiawan, E. (2017). Kajian penggunaan antibiotik pada pasien diare akut di bangsal rawat inap anak. $J$ Manajemen Pelayanan Farmasi, 17(1), 16-24.

5. Riskesdas, 2018, Hasil utama riskesdas 2108, Kementrian kesehatan, badan Penelitian dan Pengembangan Kesehatan, hal:29.

6. La Ode M.(2014).Identifikasi Drug Related Problems (DRPs) Penyakit Diare Pada Pasien 
Balita Rawat Inap di Rumah Sakit Bhayangkara Kendari Sulawesi Tenggara Tahun 2013. Skripsi pada Fakultas Farmasi Universitas Halu Oleo. Kendari.

7. Iswari Yeni.(2011).Analisis Faktor Risiko Kejadian Diare Pada Anak Usia Dibawah 2 Tahun di RSUD Koja Jakarta.Tesis.

Jakarta:Universitas Indonesia, Fakultas Ilmu Keperrawatan: tidak diterbitkan.

8. Sukawaty, Y., Helmidanora, R., dan Handayani, F. 2017, Profil Peresapan Obat Penyakit Diare pada Pasien Rawat Inap Anak di RSU Dr.Kanujoso Djatibowo Balikpapan, Jurnal Ilmu kesehatan (JIK), 5(2),130-136.

9. Almanfaluthi, M. L., \& Budi, M. H. (2017). Hubungan Antara Konsumsi Jajanan Kaki Lima Terhadap Penyakit Diare Pada Anak Sekolah Dasar. Medisains, 13(3).

10. Anugerah, Hendra, 2007, Permasalahan Umum kesehatan Anak Usia Sekolah, Artikel, online dari

Url:Http://Anugerah.Hendra.Or. id/Pasca-Nikah/3-anak-anak/Permasalahan-Umum-

Kesehatan-Anak-Usia-Sekolah/

11. Nabilah, 2015. Identifikasi Drug Related Problems (DRPS's) Diare Akut Infeksi pada Pasien Pediatri di Instalasi
Rawat Inap RS "X" di Kota Tangerang Selatan Periode Januari-Desember 2015

12. PubChem Open Chemistry Database. Cefotaxime. 2018

13. Newman ARE, Hedican EB. 2014. Impact of a guideline on management of children hospitalized with communityacquired pneumonia. Florida

14. Mohan PR. 2014. Comparison of the efficacy and safety of penicillins and cephalosporins in treatment of pediatric patients with lower respiratory tract infections. Journal

15. Susono, R. F., Sudarso, S., \& Galistiani, G. F. (2014). Cost Effectiveness Analysis Pengobatan Pasien Demam Tifoid Pediatrik Menggunakan Cefotaxime dan Chloramphenicol di Instalasi Rawat Inap RSUD Prof. Dr. Margono Soekarjo. Pharmacy, Vol. 11 No. 01 Juli 2014 ISSN : 1693-3591.

16. Hadinegoro, 2010. Buku Ajar Infeksi Dan Pediatri Tropis, Edisi Kedua, IDAI, Jakarta.

17. Mandriani E, karakteristik Penderita Demam Berdarah Dengue (DBD) yang Mengalami Dengue Syok Syndrome (DSS) Rawat Inap di RSU Dr. Pirngadi Medan Tahun 2008. FK Universitas Sumatera Utara. 